\title{
Thai Healthy Food Learning through Internet
}

\author{
Cherdpong Kheerajit and Narong Sompong
}

\begin{abstract}
This research objectives were: 1) to develop the series of online video on Thai healthy food through internet, 2) to evaluate e-learning from the online video, and 3) study the opinion of the audiences from the AEC (Asian Economic Community).

The samples of the study were 95 respondents in Indonesia and Philippines were selected by purposive sampling. Research instruments composed the online video series on Thai Healthy food which were uploading to Youtube and www.thaifoodtoworld.com, as well as a questionnaire and a structure form using in the focus group discussion.

The research found that the opinion of the respondents showed that they were mostly familiar with Thai food menus and they learned more about Thai food substantially after they had watched online video. They mostly also satisfied toward the online video at the high and highest level. The opinion of the respondents in both countries toward online video through internet was mostly found that they were suitable to use as the public relations and they satisfied at the high and highest level in terms of content, presentation techniques, convenience in watching online as well as the usefulness and implementation of the video.
\end{abstract}

Index Terms - Thai food, Thai healthy food, online video, learning through Internet.

\section{INTRODUCTION}

Thai government launched the project concern on "Thai Food to the World" with the aim of increasing the number of Thai restaurants aboard and to make Thailand to be the largest food products exporter in the world. Given the data above, Kasetsart University under the supported by National Research Council of Thailand was given a research funding to study the "Development of Thai Food Products and Proactive Promotion of Thai Food to the World". The researchers studied about the standards and characteristics of Thai food, the product status and taste of foreigners, production process for export and extending the reach of Thai food restaurants to the owners and consumers abroad [1]. The research was also found the significant of Thai food promotion to the government sectors. The research project investigated the model of multimedia integration. This study concluded that the next step of technology transfer could be implemented under an online study for target audiences in any part of the world, so everyone could be able to access this information anywhere and anytime [2] and research on the effectiveness of online education in general also shows that audiences who learn at a distance do not learn any worse, or any better, than traditional audiences [3]. Consequently, the researcher then continuingly studies furthermore on the Thai Healthy Food Learning through Internet the target audiences

Manuscript received May 5, 2014; revised July 7, 2014.

Cherdpong Kheerajit is with Kasetsart University, Thailand (e-mail: agrcpk@ku.ac.th). aboard especially the countries in the AEC (Asian Economic Community) who were the Thai restaurant owners, Thai and foreigner chefs and the instructors and students who were involved Thai cuisine.

\section{ReseARCh OBJeCtives}

The objectives of this research aim to: 1) to develop the series of online video on Thai healthy food through internet from Thai food research project for support the transfer of technology Thai food research, 2) to evaluate e-learning from online video through internet and social network and 3) study the opinion of the audiences from the AEC.

\section{RESEARCH METHODOLOGY}

\section{A. Sample of the Study}

The study follows a one-shot survey research design. The respondents of this survey were divided based on two main groups' activities: 1) 8 subject matter specialists and experts on Thai Food and 5 media specialists in public relations; 2) 95 foreigners and Thais who were Thai food consumers, Chefs, and businessmen in Indonesia and Philippines were selected by purposive sampling.

\section{B. Research Instruments}

Research instruments composed of 6 online video series on Thai Healthy food which were upload to Youtube and website www.thaifoodtoworld.com, as well as one questionnaire and one structure form using in the focus group discussion.

\section{Data Collection}

The online video was uploaded to Youtube and website www.thaifoodtoworld.com for testing and using with the samples at Thai restaurants in Indonesia and Philippines. The samples were requested to fill out the questionnaires after they watched the video. Perception of audiences' opinion was measured using a five-point following Likert scale.

$\begin{array}{lc}\text { Level } & \text { Scale } \\ \text { Very good } & 5 \\ \text { Good } & 4 \\ \text { Fair } & 3 \\ \text { Poor } & 2 \\ \text { Very Poor } & 1\end{array}$

The mean of the audiences' opinion was measured through the following:
Level
The range of the mean audiences' opinion Scores
Very good $4.00-5.00$ 


$\begin{array}{ll}\text { Good } & 2.00-3.99 \\ \text { Fair } & 2.00-2.99 \\ \text { Poor } & 1.00-1.99 \\ \text { Very Poor } & 0.00-0.99\end{array}$

\section{Data Analysis}

Data were analyzed by SPSS for windows. Statistical uses were mean, standard deviation, and percentage.

\section{RESUlT AND DiscUSSION}

\section{A. Focus Group Discussion}

The researchers had set up the focus group discussion to find out the content and format for the video. The results of the focus group discussion described the content presentation should be easy and convenience for understanding and no longer 10 minutes. The content should be composing the history of the food, characteristics of Thai food, preparing-cooking-decoration of Thai food, and Nutrition.

\section{B. Thai Healthy Food through Internet}

The audiences who watched the video "Thai Healthy food" through internet by Youtube and www.thaifoodtoworld.com in Indonesia and Philippines were the government officers, private enterprise, students and independent profession. Almost of respondents were the foreigners in Indonesia and Philippines and some Thai officers and workers in those countries.

The opinion of the respondents who had watched online video showed that they were mostly familiar with the six Thai food menus, especially Tom Yum Koong, and Pad Thai. They learned more about Thai Food substantially after they had watched online video. They mostly also satisfied toward the online video at the high and highest level. Most of the Indonesian and Filipino respondents liked Tom Yum Koong at the highest level, following by Pad Thai. The Indonesian would come to eat Thai Food 1-3 times a month, and Filipino would be 1 time for 3 months. The reasons why they come to eat Thai food were the Taste, following by the nutritious values of Thai food.

TABLE I: THE AUDIENCES' OPINION ABOUT THE CONTENT ON VIDEO ONLINE “THAi HEALTHY FOOD LEARNING THROUGH INTERNET"

\begin{tabular}{|c|c|c|c|c|c|c|}
\hline \multirow{3}{*}{ Evaluation Lists } & \multicolumn{6}{|c|}{ Opinion } \\
\hline & \multicolumn{4}{|c|}{ Indonesia } & \multicolumn{2}{|c|}{ Philippines } \\
\hline & $\bar{x}$ & S.D. & Level & $\bar{x}$ & S.D. & Level \\
\hline $\begin{array}{l}\text { 1. The objectives of these } \\
\text { videos }\end{array}$ & 4.35 & 0.53 & Very good & 4.59 & 0.61 & Very good \\
\hline 2. Suitable contents & 4.41 & 0.57 & Very good & 4.59 & 0.50 & Very good \\
\hline 3. Contents clarify & 3.98 & 0.59 & good & 4.62 & 0.55 & Very good \\
\hline $\begin{array}{l}\text { 4. Contents easy to } \\
\text { understandin }\end{array}$ & 4.33 & 0.69 & Very good & 4.69 & 0.54 & Very good \\
\hline
\end{tabular}

TABLE II: THE AUDIENCES' OPINION ABOUT THE PRESENTATIONS ON VIDEO ONLINE “THAI HEALTHY FOOD LEARNING THROUGH INTERNET”

\begin{tabular}{|c|c|c|c|c|c|c|}
\hline \multirow{3}{*}{ Evaluation Lists } & \multicolumn{6}{|c|}{ Opinion } \\
\hline & \multicolumn{3}{|c|}{ Indonesia } & \multicolumn{3}{|c|}{ Philippines } \\
\hline & $\bar{x}$ & S.D. & Level & $\bar{x}$ & S.D. & Level \\
\hline $\begin{array}{l}\text { 1. Presenting in documentary } \\
\text { video }\end{array}$ & 4.19 & 0.63 & Very good & 4.59 & 0.61 & Very good \\
\hline $\begin{array}{l}\text { 2. The approach for presenting } \\
\text { on video and sound }\end{array}$ & 4.22 & 0.66 & Very good & 4.59 & 0.56 & Very good \\
\hline $\begin{array}{l}\text { 3. Suitable font sizes which is } \\
\text { easy for watching }\end{array}$ & 4.17 & 0.56 & Very good & 4.56 & 0.62 & Very good \\
\hline 4. Video clarity & 3.87 & 0.65 & good & 4.66 & 0.55 & Very good \\
\hline 5. Sound and music are clear & 4.38 & 0.67 & Very good & 4.66 & 0.60 & Very good \\
\hline $\begin{array}{l}\text { 6. Animations and graphics } \\
\text { helped in understanding in the } \\
\text { contents }\end{array}$ & 4.24 & 0.69 & Very good & 4.44 & 0.67 & Very good \\
\hline
\end{tabular}

Table I shows that majority of the audiences' opinion about the content on video online "Thai Healthy Food Learning through Internet" were very good level. In Indonesia, the highest was suitable contents, and contents easy to understanding were the highest in Philippines. That means all of the respondents have satisfaction on the video online especially on contents easy to understanding.

The opinion of the respondents in both countries toward online video through internet was mostly found that they were suitable to use as the public relations and they satisfied at the high and highest level in terms of content, presentation techniques, convenience in watching online as well as the usefulness and implementation of the video.

Table II shows that almost of the audiences' opinion about the presentations on video online "Thai Healthy Food" were very good level. The highest was sound and music in the video is clear both of Indonesia and Philippines because the researchers had set up the focus group discussion with subject 
matter specialists and experts on Thai Food and media specialists in public relations to find out the suitable contents and format before producing the video. That is the reason why the presentations on this video online were almost very good level.

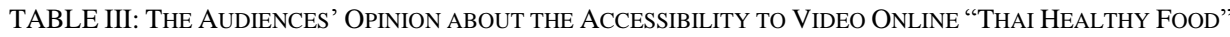

\begin{tabular}{|c|c|c|c|c|c|c|}
\hline \multirow{3}{*}{ Evaluation Lists } & \multicolumn{6}{|c|}{ Opinion } \\
\hline & \multicolumn{3}{|c|}{ Indonesia } & \multicolumn{3}{|c|}{ Philippines } \\
\hline & $\bar{x}$ & S.D. & Level & $\bar{x}$ & S.D. & Level \\
\hline $\begin{array}{l}\text { 1. Convenience in connecting } \\
\text { internet }\end{array}$ & 4.13 & 0.69 & Very good & 4.33 & 0.72 & Very good \\
\hline $\begin{array}{l}\text { 2. Fast in accessing the video } \\
\text { online }\end{array}$ & 3.83 & 0.69 & good & 4.06 & 0.88 & Very good \\
\hline $\begin{array}{l}\text { 3. Modern Computer and devices } \\
\text { support usability }\end{array}$ & 3.69 & 0.67 & good & 4.40 & 0.63 & Very good \\
\hline 4. Internet network stability & 3.96 & 0.77 & good & 4.06 & 0.59 & Very good \\
\hline
\end{tabular}

TABLE IV: THE AUDIENCES’ OPINION ABOUT THE BENEFICIAL AND USEFULNESS TOWARD VidEO ONLINE “THAI HEALTHY FOOD”

\begin{tabular}{|c|c|c|c|c|c|c|}
\hline \multirow{3}{*}{ Evaluation Lists } & \multicolumn{6}{|c|}{ Opinion } \\
\hline & \multicolumn{3}{|c|}{ Indonesia } & \multicolumn{3}{|c|}{ Philippines } \\
\hline & $\bar{x}$ & S.D. & Level & $\bar{x}$ & S.D. & Level \\
\hline 1. Thai food database & 3.48 & 0.61 & good & 4.53 & 0.62 & Very good \\
\hline $\begin{array}{l}\text { 2. Disseminate knowledge and } \\
\text { promoting Thai food research }\end{array}$ & 3.46 & 0.63 & good & 4.59 & 0.61 & Very good \\
\hline $\begin{array}{l}\text { 3. Can be used as reference for } \\
\text { other Thai food research }\end{array}$ & 3.65 & 0.59 & good & 4.69 & 0.47 & Very good \\
\hline $\begin{array}{l}\text { 4. Valuable for students, } \\
\text { professors, and researchers }\end{array}$ & 3.60 & 0.71 & good & 4.69 & 0.47 & Very good \\
\hline $\begin{array}{l}\text { 5. There are effect to consumers } \\
\text { who would like to eat Thai food }\end{array}$ & 3.60 & 0.64 & good & 4.50 & 0.62 & Very good \\
\hline
\end{tabular}

Table III shows that almost of the audiences' opinion about the accessibility to video online "Thai Healthy Food" was very good level in Philippines and good level in Indonesia. That means the respondents in Philippines have accessibility to video online better than the respondents in Indonesia because the learning's achievements of audiences depend on the readiness and needs of the target audiences if they can access the resources and the facilities of Internet, they are ready to participate in the program and learn with their self-pace [4].

Table IV shows that all of the respondents' opinion toward video online on "Thai Healthy Food" from Indonesia was good level. The highest mean was the video can be used as reference for other Thai food research. In Philippines, all of the respondents' opinion was very good level and the highest mean also was the video can be used as reference for other Thai food research and Valuable for students, professors, and researchers.

\section{DISCUSSIONS AND CONCLUSIONS}

Thai Healthy Food Learning through Internet is an innovative channel to promoting Thai cuisine and health benefit learning. It was highly benefits to the audiences under the international context. The audiences can learn from anywhere, anytime with the distance media because technology has become the key to a new world of education. Online learning has become one of the most popular ways of gaining access to an education [5]. The results of this research shown that the respondents from Indonesia and Philippines satisfied at the good and very good level in terms of content, presentation techniques, convenience in watching video online as well as the usefulness and implementation of the video. That means the video online suitable to use as the public relations to promoting Thai food to both of Indonesia and Philippines.

\section{ACKNOWLEDGEMENT}

The authors wish to thanks Department of Educational Technology, Faculty of Education and Department of Agricultural Extension and Communication, Faculty of Agriculture Kamphange Saen, Kasetsart University for their supported facilities in making this project possible. This research project was financially supported by National Research Council of Thailand (NRCT).

\section{REFERENCES}

[1] W. Varanyanond, The Development of Safety Thai Food for Thai Kitchen to the World Project and Thai Food Proactive Promotions, Research Report Submitted to National Research Council of Thailand, Institute of Food Research and Development, Kasetsart University, 2008.

[2] N. Sompong, "Proactive promotion strategies and multimedia development and utilization in the "thai food to the world'," in Proc. International Conference on Developing Tomorrow's Leaders in Agriculture and Rural Development: Responding to the Challenges of Globalization, Los Banos, Laguna, Philippines: Searca, 2010, pp. 39-45.

[3] M. Simonson, S. Smaldino, M. Albright, and S. Zvacek, Teaching and Learning at a dIstance: Foundations of Distance Education, 2nd ed., Upper Saddle River, NJ: Merrill Prentice Hall. Statistics, US Department of Education, 2003. 
[4] N. Sompong and C. Kheerajit, "Development of online courseware on Thai food good healthy," TOJET: The Turkish Online Journal of Educational Technology, vol. 11, iss. 4, October 2012.

[5] J. C. Setzer and L. Lewis, Distance Education Courses for Public Elementary And Secondary School Students: 2002-2003, Washington, DC: National Center for Education, 2005.

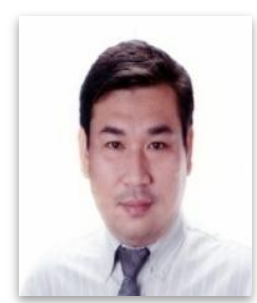

Cherdpong Kheerajit is a Ph.D. He was born in Thailand on April 25, 1980. He received his B.Ed. in educational technology from Burapha University (1998-2002), and M.Ed. in educational technology from Kasetsart University, Thailand (Academic Achievement Award), (2003-2005). And he obtained his Ph.D. in development communication from University of the Philippines Los Baños, Philippines from 2010 to 2013.

He started working in the Department of Agricultural Extension and as a communication professor in Kasetsart University, Kamphaeng Saen Campus in 2006. His research interest include e-learning, public relations media, agricultural extension and communication, media production, and development communication.

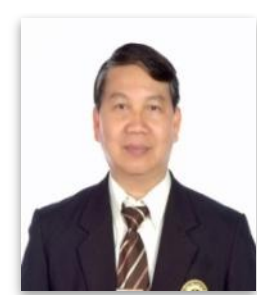

Narong Sompong is a Ph.d. he was born in Thailand on October 2, 1951. He received his B.Ed. in secondary education, Srinakarinwirot University, Prasarnmit, Thailand, 1973, M.Ed. in educational technology, Srinakarinwirot University, Prasarnmit, Thailand, 1976, and Ph.D. in development communication, University of the Philippines Los Baños, Philippines, 1991.

He is an associate professor at the Department of Educational Technology, Faculty of Education, Kasetsart University, Bangkok, Thailand.

$\mathrm{He}$ is currently the chairman of Doctoral Degree Special Program in educational communications and technology. His research concerns were in the field of educational technology, e-learning, instructional media design and production, knowledge management in education, multimedia design and development, television program and photography in education. 